\title{
Neuroligand-Evoked Calcium-Dependent Release of Excitatory Amino Acids from Schwann Cells
}

\author{
Vladimir Parpura,, ${ }^{1, a}$ Fang Liu ${ }^{2, b}$ Ksenija V. Jeftinija, ${ }^{2}$ Philip G. Haydon, ${ }^{1}$ and Srdija D. Jeftinija ${ }^{2}$ \\ 'Department of Zoology and Genetics and 'Department of Veterinary Anatomy, Signal Transduction Training Group, \\ Neuroscience Program, lowa State University, Ames, lowa 50011
}

\begin{abstract}
Bradykinin caused a receptor-mediated increase in release of the excitatory amino acids (EAAs) glutamate and aspartate from Schwann cell cultures obtained from dorsal root ganglia (DRG) together with an increase in the cytoplasmic level of free calcium. Perturbations which inhibited bradykinin-induced calcium mobilization prevented the release of EAAs from glia. The addition of ionomycin caused a calcium-dependent release of EAAs. Therefore, bradykinin causes calcium dependent-release of EAAs from DRG Schwann cells. Bradykinin did not cause cell swelling and p-chloromercuriphenylsulfonic acid, an inhibitor of the electrogenic glutamate transporter, did not reduce bradykinin-induced EAA release. Therefore, bradykinin stimulates EAA release from Schwann cells through a mechanism that is neither the previously described volume regulated release mechanism nor due to the reversal of the glutamate transporter.
\end{abstract}

[Key words: bradykinin, calcium, glutamate, secretion, Schwann cells, Fura-2, furosemide]

It has been well established that glia have multiple roles in the nervous system which include the regulation of external potassium and the uptake of the excitatory amino acids glutamate and aspartate which are released from neurons into the extracellular space (Nicholls and Atwell, 1990; Barres, 1991; Kanai et al., 1993). Several lines of evidence suggest that glial cells may also play important roles in releasing neurotransmitters. Schwann cells can release $\mathrm{ACh}$ following axotomy of motoncurons (Dennis and Miledi, 1974). Retinal Müller cell depolarization stimulates the release of glutamate through a reversal of an electrogenic glutamate uptake carrier (Szwatkovski et al., 1990). Depolarization causes the calcium-dependent release of the amino acid taurine from hippocampal glia (Philibert et al., 1988). Hy-

\footnotetext{
Received June 17, 1994; revised Apr. 7, 1995; accepted Apr. 12, 1995.

V.P. and F.L. contributed equally. We thank T. A. Basarsky, H. S. Gill, M. McCloskey, D. S. Sakaguchi, S. Shen, and L. Urban for comments on the manuscript. We also thank D. S. Sakaguchi for help with immunocytochemistry and S. Shen for assistance with BCECF studies. Antibodies were generously supplied by Drs. R. Jahn (anti-synaptophysin and anti-synaptotagmin) and E. M. Johnson, Jr. (anti-NGF receptor). This work was supported by the Epilepsy Foundation of America, the McKnight Foundation and NIH grants to S.J. and P.G.H. and by an NSF training grant.

Correspondence should be addressed to Srdija Jeftinija, Department of Veterinary Anatomy, 1098 Veterinary Medicine Building, Iowa State University, Ames, IA 50011.

aPresent address: Department of Physiology and Biophysics, Mayo Clinic, Rochester, MN 55905

'Present address: Division of Neurobiology, Cornell University Medical College, New York, NY 10021

Copyright (C) 1995 Society for Neuroscience $0270-6474 / 95 / 155831-09 \$ 05.00 / 0$
}

posmotic shock of cortical astrocytes stimulates cell swelling, an increase in internal calcium and a correlated release of the amino acids aspartate and taurine (Kimelberg et al., 1990; O'Connor and Kimelberg, 1993). Since glial cell calcium levels are regulated by neurotransmitters (Reisner et al., 1989; CornellBell et al., 1990; Glaum et al., 1990; Charles et al., 1991; Cornell-Bell and Finkbeiner, 1991; Inagaki et al., 1991; Jensen and Chiu, 1991; McCarthy and Salm, 1991), this has prompted us to ask whether the neuroligand bradykinin causes a calciumdependent release of excitatory amino acids (EAAs) from glial cells.

In the PNS, the nonapeptide bradykinin is released from its precursors, the kininogens, by the action of the enzyme kallikrein in response to trauma (Dray and Perkins, 1993). Bradykinin is known to mobilize calcium from inositol 1,4,5-trisphosphate $\left(\mathrm{IP}_{3}\right)$-sensitive calcium stores in several cell types (for references, see Miller, 1987; Higashida and Ogura, 1991). Since bradykinin can mobilize internal calcium, we have asked whether this agent can cause the relcase of excitatory amino acids from glial cells derived from the dorsal root ganglia. This study demonstrates that the neuroligand, bradykinin, mobilizes internal calcium from Schwann cells which stimulates a calcium-dependent release of the excitatory amino acids, glutamate and aspartate.

A brief account of this werk has been reported previously (Liu et al., 1992; Jeftinija et al., 1994)

\section{Materials and Methods}

Cell culture. Glial cultures from DRG were obtained by modification of the organotypic procedure (Gähwiler, 1984). Following anesthesia with ether and decapitation, DRG from 1-2 d old Sprague-Dawley rats were rapidly removed and washed in cold $\left(4^{\circ} \mathrm{C}\right)$ oxygenated Gey's balanced salt solution (GBSS, GIBCO) modified by the addition of $2 \%$ glucose. The capsular sheet was carefully removed form the DRG to minimize fibroblast contamination. DRG were then embedded onto a glass coverslip inlaid in a $35 \mathrm{~mm}$ dish (for release studies) or into a glass bottomed dish (for calcium imaging) in a plasma-thrombin clot. Cultures were maintained at $36^{\circ} \mathrm{C}$ in a humidified $5 \% \quad \mathrm{CO}_{2} /$ air atmosphere. The culture medium consisted of $25 \%$ horse serum (GIBCO), 25\% Earle's Balanced Salt Solution (GIBCO), and 50\% Basal Medium Eagle (GIBCO) containing $36 \mathrm{~mm}$ glucose. The central part of explants which contains neuronal cell bodies was removed from established cultures (4-7 $\mathrm{d}$ in culture). The residual glial cells were maintained for additional $72 \mathrm{hr}$ when all experiments were performed. Neurites degenerated 24-48 $\mathrm{hr}$ following the removal of the central portion of explants leaving cultures containing only non-neuronal cells. The absence of neuronal elements was confirmed by immunocytochemistry.

In some experiments we enriched the number of Schwann cells in cultures using two methods (see Kleitman et al., 1992). In the Wood method, DRG were cultured for 48-96 hr in the presence of cytosine arabinoside (Ara-C, $5 \mu \mathrm{g} / \mathrm{ml}$ ). They were then transplanted to a new coverslip coated with chicken plasma. DRG explants were then cultured 
as described above to obtain DRG glia. In the Brockes method, DRG glia were incubated with Thy 1.1 antibody (hybridoma supernatant, American Type Culture, No. TIB103) and addition of rabbit complement (Sigma). Since Thy 1.1 is expressed on fibroblasts, but not on Schwann cells, this procedure leads to a complement mediated lysis of fibroblasts. In both culture methods, immunocytochemistry revealed that Schwann cells were enriched to $>95 \%$.

In some experiments we prepared fibroblast enriched culture using previously described procedure (Levison and McCarthy, 1992). Immunocytochemistry revealed absence of neurons and Schwann cells and presence of about 5\% GFAP positive cells.

Immunocytochemistry. Antibody visualization was accomplished by using a Vectastain $A B C$ kit (Vector) and the nickel-enhanced DAB method (Hsu et al., 1981). Immunocytochemistry was performed using antibodies directed against the synaptic proteins synaptophysin (1:1000; clone $7.4 \mathrm{a}$, provided by $\mathrm{R}$. Jahn) and synaptotagmin (1:5000; clone 41.1, provided by R. Jahn), against glial fibrillary acidic protein (GFAP; 1:5000, ICN Immunobiologicals) and against the low-affinity NGF receptor $(1: 2000 ; 192-\mathrm{IgG}$, provided by E. M. Johnson, Jr.). Anti-synaptophysin, synaptotagmin, and anti-GFAP were found to be negative on DRG glia. Positive controls were performed with these antibodies using hippocampal neurons and astroglia and using DRG explants in which axons were maintained in culture.

EAA release. The coverslips with glial cultures were mounted into a $50 \mu \mathrm{l}$ perfusion chamber. A modified Ringer's perfusion solution containing (in $\mathrm{mM}$ ) $\mathrm{NaCl} 128, \mathrm{KCl} 1.9, \mathrm{KH}_{2} \mathrm{PO}_{4} 1.2, \mathrm{CaCl}_{2} 2.4, \mathrm{MgSO}_{4}$ $1.3, \mathrm{NaHCO}_{3} 26$, and glucose $10\left(\mathrm{pH} \mathrm{7.4)}\right.$ bubbled with $95 \% \mathrm{O}_{2}, 5 \%$ $\mathrm{CO}_{2}$ was used for constant flow through at a rate of $200 \mu \mathrm{l} / \mathrm{min}$ and $35-37^{\circ} \mathrm{C}$. After an equilibration period of $40-60 \mathrm{~min}$, samples of perfusate for amino acid determination were collected every minute. The amino acid content in samples was determined by high-performance liquid chromatography (HPI.C) with fluorescence detection (Lindroth and Mopper, 1979). Prior to injection, aliquots of samples were derivatized with $o$-phthalic aldehyde (OPA) 2-mercaptoethanol reagent (Pierce). Chromatography was performed on a $15 \mathrm{~cm}$ Microsorb-MV HPLC column (Rainin Instrument $\mathrm{Co}$.) using a sodium acetate methanol gradient (pH 5.9). Bradykinin (10 nM; Sigma) and its antagonist (D$\mathrm{Arg}^{0}, \mathrm{Hyp}^{3}, \beta-\mathrm{Thi}^{5.8}, \mathrm{D}-\mathrm{Phe}^{7}$ )-bradykinin (5 $\mu \mathrm{M}$; Bachem Bioscience Inc.) were added to a perfusion solution. In control experiments we coadministered hydroxyproline (180 $\mathrm{nm}$ ) together with bradykinin and determined that there is a 1 min lag time from initiation of the addition of an agent until it is collected for HPLC analysis due to dead-volume in the chamber. All figures for HPLC have been correspondingly corrected. Elevated $\mathrm{K}^{+}(50 \mathrm{mM}$ ) solution for HPLC was prepared by modification of a Ringer's solution where $\mathrm{NaCl}$ was replaced by $\mathrm{KCl}$.

Calcium imaging. Cells were loaded with fura-2 AM ( $4 \mu \mathrm{M}$; Molecular Probes) for $40-60 \mathrm{~min}$ at $37^{\circ} \mathrm{C}$. One microliter of $25 \%(\mathrm{w} / \mathrm{w})$ of Pluronic F-127 (Molecular Probes) was mixed with $1 \mathrm{ml}$ of $4 \mu \mathrm{M}$ Fura-2 AM ester solution. After washing, cells were kept for $30-60$ min at $37^{\circ} \mathrm{C}$ to permit dye de-esterification. All experiments took place at 22 $24^{\circ} \mathrm{C}$. All image processing and analysis were performed using ratiometric software (QFM, Quantex Corp. or IMAGE-1/Fl, v. 1.63g, Universal Imaging Corp.). Fura-2 fluorescence was excited by a xenon-arc lamp using $340 \mathrm{~nm}$ or $350 \mathrm{~nm}$ and $380 \mathrm{~nm}$ bandpass filters. Exciter filters were exchanged using a rotation filter wheel (Ludl 6-position). Neutral density filters were placed in the light path to prevent cell damage and to reduce photobleaching of fura-2. Fura-2 emission (510 DF $40 \mathrm{~nm}$ filter) was collected using an SIT camera (Hammamatsu). Background subtracted, ratio images $(340 / 380 \mathrm{~nm}$ or $350 / 380 \mathrm{~nm}$ ) were used to calculate the $\left[\mathrm{Ca}^{2+}\right]_{i}$ according to Equation 5 of Grynkiewicz et al. (1985). Calibration was performed in situ (Thomas and Delaville, 1991) using the $\mathrm{Ca}^{2+}$-ionophore 4-bromo-A23187 (10 $\mu \mathrm{M}$, Molecular Probes). An estimate of autofluorescence at each wavelength was achieved by addition of $\mathrm{MnCl}_{2}(20 \mathrm{mM})$. Cells were included in analysis if the first addition of bradykinin caused a $\left[\mathrm{Ca}^{2+}\right]_{i}$ accumulation that was greater than $50 \%$ of the resting calcium level.

During calcium imaging, bradykinin and elevated $\mathrm{K}^{+}(50 \mathrm{~mm})$ were applied to glia for $1 \mathrm{~min}$ by pressure ejection from a puffer pipette (opening diameter $\sim 2-3 \mu \mathrm{m}, 10 \mathrm{psi}$ ). All other drugs were uniformly applied to the bath by flow through. Repeated applications of bradykinin were spaced at $10 \mathrm{~min}$ intervals. In some experiments the second bradykinin application followed the first application after $30 \mathrm{~min}$. Ryanodine $(10 \mu \mathrm{M})$, caffeine $(10 \mathrm{mM})$, and furosemide $(5 \mathrm{mM})$ were applied 10 min prior to the second application of bradykinin while thapsigargin was applied to the bath 30 min prior to the second application of bra- dykinin. Thapsigargin $(1 \mu \mathrm{M})$ was dissolved in dry DMSO. Control experiments with $0.1 \%(\mathrm{v} / \mathrm{v}) \mathrm{DMSO}$ showed that DMSO did not affect the action of bradykinin. Normal saline contained (in $\mathrm{mM}$ ) $\mathrm{NaCl} 140$, $\mathrm{KCl} 5, \mathrm{MgCl}_{2} 2, \mathrm{CaCl}_{2}$ 2, and HEPES 10 (pH 7.4). Calcium-depleted solution contained (in $\mathrm{mM}$ ) $\mathrm{NaCl} 128, \mathrm{KCl} 1.9, \mathrm{KH}_{2} \mathrm{PO}_{4} 1.2, \mathrm{CaCl}_{2} 0.2$, EGTA $1, \mathrm{MgSO}_{4} 2.5, \mathrm{NaHCO}_{3} 26$, and glucose 10 (pH 7.4). Elevated $\mathrm{K}^{+}$saline was prepared by modification of normal saline where $\mathrm{NaCl}$ was replaced by $\mathrm{KCl}$.

MAX CHElator (v. 5.6), written by Chris Patton at Stanford University, was used to calculate free extracellular calcium levels. The calculation includes a correction for extracellular $\mathrm{Mg}^{2+}$ ions.

Cell volume measurement. To determine whether bradykinin caused a shrinkage of cells in our studies we monitored cell volume using BCECF as described by Eriksson et al. (1992). Cells were loaded by incubation in membrane permeable BCECF AM (10 $\mu \mathrm{M})$ for $40-60$ min, followed by 40 min for de-esterification. BCECF was excited at the $\mathrm{pH}$-insensitive wavelength of $440 \mathrm{~nm}$. The emission intensity (510 DF $40 \mathrm{~nm}$ bandpass) was monitored with a SIT camera. When cells swell, BCECF is diluted, reducing the fluorescent intensity detected. We confirmed that this approach effectively detected volume changes in our studies by applying hyposmotic saline that was made by removing 50 $\mathrm{mm}$ of $\mathrm{NaCl}$ from our standard saline (see above).

\section{Results}

Bradykinin stimulates excitatory amino acid release from dorsal root ganglia Schwann cells

Primary glial cultures of dorsal root ganglia (DRG) were obtained using a modification of the organotypic procedure (Gähwiler, 1984). Dorsal root ganglia were cultured on coverslips to permit neurite extension and migration of glial cells. After cultures were established, the central portion of the ganglionic explant, which contains neuronal cell bodies, was removed from the culture. During the next 48 hr the residual neurites degenerated leaving a neuron-free glial cell culture. The release of EAAs from these cultures was assayed using HPLC on the superfusate. The basal release of glutamate and aspartate into superfusate produced levels of $26 \pm 2 \mathrm{nM}$ (mean $\pm \mathrm{SEM} ; n=$ 13) and $6 \pm 1 \mathrm{nM}$, respectively. Addition of bradykinin caused a dose-dependent increase in release of the EAAs glutamate and aspartate from glial cultures. The threshold concentration of bradykinin was $1 \mathrm{nM} ; 10 \mathrm{nM}$ bradykinin caused a greater than ninefold increase in the release of glutamate to $239 \pm 42 \mathrm{nM}$ and a greater than threefold increase in aspartate to $21 \pm 3 \mathrm{nM}(n=$ 12; Fig. $1 A, B)$. A second application of bradykinin $(n=12)$ similarly caused EAA release, although the magnitude of this response was attenuated (Fig. 1A,B). This action is receptormediated since the $\mathrm{B}_{2}$ receptor antagonist, (D-Argo $\mathrm{Hyp}^{3}$, $\beta$-Thi ${ }^{5,8}$, D-Phe $\left.{ }^{7}\right)$-bradykinin $(5 \mu \mathrm{M})$, reversibly blocked the stimulatory action of bradykinin $(n=6$; Fig. $1 C)$. While bradykinin stimulated the release of glutamate and aspartate from glial cultures it did not significantly affect the release of serine. The basal level of serine was $14 \pm 2 \mathrm{~nm}$ compared to $16 \pm 2 \mathrm{nM}$ in the presence of bradykinin ( $n=13 ; p>0.5$ ). These data demonstrate that the nonapeptide bradykinin potently causes the selective release of the EAAs glutamate and aspartate from DRG glia.

The cell types present in the glial cultures derived from DRG was examined using immunocytochemistry. We confirmed that glial cultures were neuron-free by using antibodies against the synaptic proteins synaptophysin and synaptotagmin. In these cultures immunoreactivity for these two synaptic proteins was absent while neurons were immunopositive in separate cultures. An antibody against glial fibrillary acidic protein was negative in DRG glial cultures. However, using an antibody against the low-affinity NGF receptor, characteristically expressed in Schwann cells localized distal to the site of axotomy, but not in surrounding fibroblasts (Taniuchi et al., 1988), we found that 
$\mathbf{A}$

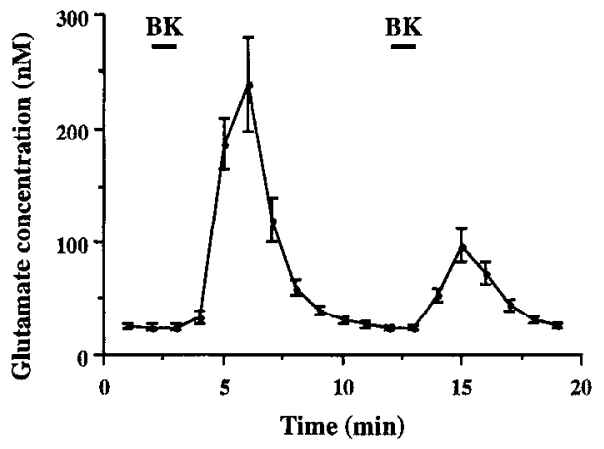

B

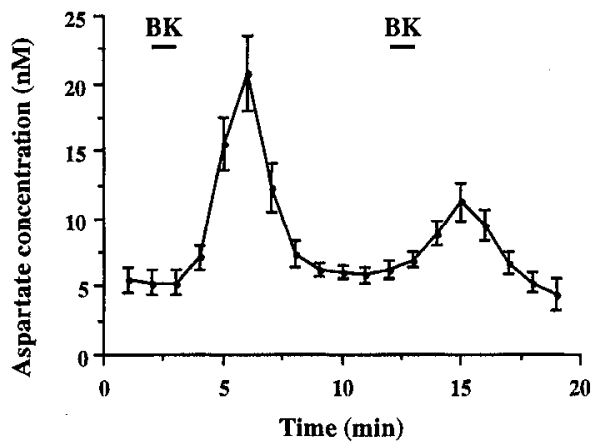

C

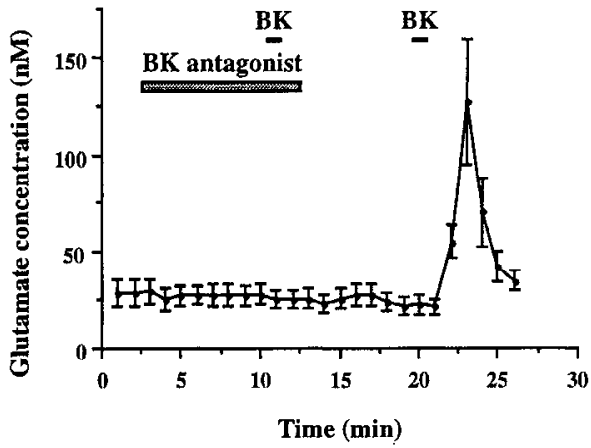

Figure 1. Bradykinin causes a receptor-mediated release of the EAAs, glutamate and aspartate, from DRG glia. Using HPLC, the amounts of glutamate and aspartate were determined in superfusate from rat DRG glia cultures. Addition of bradykinin $(B K, 10 \mathrm{nM})$ caused a ninefold elevation of glutamate release $(A)$ and a threefold elevation of aspartate release $(B)$. The $\mathrm{B}_{2}$ receptor antagonist, (D-Arg ${ }^{0}, \mathrm{Hyp}^{3}, \beta-\mathrm{Thi}^{5,8}, \mathrm{D}-\mathrm{Phe}^{7}$ )bradykinin, blocked the secretory action of bradykinin $(C)$. After washout of the antagonist, bradykinin reliably increased glutamate release. Points represent means \pm SEM.

about $74 \%$ of the cultured glial cells possess NGF receptors (Fig. 2). Therefore the predominant glial cell type in these DRG cultures is Schwann cells.

As fibroblasts are likely to be a contaminating cell type in these cultures, we modified our techniques to enrich specifically in Schwann cells. Purified populations of Schwann cells ( $>95 \%$ of cells) were obtained by the Wood $(n=6)$ and Brockes $(n=$ 6) methods (see Kleitman et al., 1992). These cultures showed similar increases of the EAAs glutamate and aspartate in the superfusate after application of bradykinin. Bradykinin increased the glutamate levels in the superfusate from a basal level of 127 $\pm 9 \mathrm{nM}$ and $35 \pm 7 \mathrm{nM}$ to $465 \pm 23 \mathrm{nM}$ and $123 \pm 16 \mathrm{nM}$ using the Brockes and Wood methods, respectively. Fibroblast enriched cultures showed no significant increase in glutamate release after application of bradykinin (basal level $179 \pm 17 \mathrm{nM}$; after bradykinim $226 \perp 23$ пм; $n=4 ; p>0.2$ ). However, subsequent application of hyposmotic saline caused increase of glutamate in superfusate from a basal level of $160 \pm 37 \mathrm{nM}$ to 1074 $\pm 143 \mathrm{nM}(n=4 ; p<0.02)$. We therefore conclude that the nonapeptide, bradykinin causes the release of the amino acids glutamate and aspartate from DRG Schwann cells.

Bradykinin mobilizes calcium in dorsal root ganglion Schwann cells

The release of neurotransmitter at neuronal synapses is calcium dependent. To ask whether calcium might play a role in bradykinin-induced EAA release from DRG Schwann cells, we used ratiometric imaging techniques to monitor glial calcium levels. Cells were loaded with the membrane permeant calcium indicator fura-2 AM. Glia were imaged at low plating density, where they did not form a confluent monolayer. In resting conditions, the cytoplasmic calcium level of glia was $102 \pm 2 \mathrm{nM}(n=$ 136). Bradykinin (10 $\mathrm{nM}$ ) reliably raised the cytoplasmic level of free calcium in $72 \%$ of cells tested $(n=136$ of 188). This increase of intracellular calcium reached the peak level of 747 $\pm 24 \mathrm{nM}(n=136$; Fig. $3 A)$ about $20 \mathrm{sec}$ after the onset of bradykinin application and was sustained for several minutes. In all subsequent experiments, we have reported the calcium levels for only those cells that responded to bradykinin. These bradykinin responsive cells had the morphology of Schwann cells. In some experiments we performed immunocytochemistry following calcium imaging using the antibody directed against the lowaffinity NGF receptor which is present in Schwann cell cultures. Immunocytochemistry demonstrated that those cells that responded to bradykinin with an elevation of internal calcium were immunopositive with the antibody directed against the low-affinity NGF-receptor ( $n=22$ of 22 cells). Therefore, bradykinin elevates internal calcium levels in Schwann cells in a manner temporally coincident with the timing of release of glutamate and aspartate.

Repeated applications of bradykinin reliably elevated calcium levels in Schwann cells (Fig. $3 B$ ). The $B_{2}$ receptor antagonist (D-Arg ${ }^{0}, \mathrm{Hyp}^{3}, \beta-\mathrm{Thi}^{5.8}, \mathrm{D}^{\mathrm{s}} \mathrm{Phe}^{7}$ )-bradykinin $(5 \mu \mathrm{M})$, reversibly attenuated the stimulatory action of bradykinin on calcium mobilization. In the presence of the $B_{2}$ receptor antagonist, the average resting calcium level $(107 \pm 3 \mathrm{nM})$ was moderately increased by application of bradykinin ( $151 \pm 11 \mathrm{nM} ; n=32)$. However, after washout of the antagonist, bradykinin increased the cytoplasmic calcium level to $480 \pm 24 \mathrm{nM}(n=32)$, a value significantly greater than in the presence of the $\mathrm{B}_{2}$ receptor antagonist (Scheffé's test, $p<0.001$ ).

Removal of external calcium from the bathing medium did not prevent the initial calcium mobilizing action of bradykinin (Fig. $3 C$ ). Cells were bathed in a calcium-depleted saline containing $0.2 \mathrm{~mm}$ calcium with the addition of $1 \mathrm{~mm}$ EGTA to yield an estimated free extracellular calcium level of $24 \mathrm{nM}$. We found that it was necessary to have some calcium in the bathing medium otherwise cells detached from the culture substrate. In this calcium-depleted saline, bradykinin elevated cytoplasmic free calcium from $98 \pm 2 \mathrm{nM}$ to $713 \pm 38 \mathrm{nM}(n=36)$. However, subsequent additions of bradykinin in calcium-depleted bathing medium had little calcium mobilizing action $(n=36$ and $n=23$ for the second and third applications, respectively; Fig. $3 C$ ). These data suggest that bradykinin mobilizes calcium 


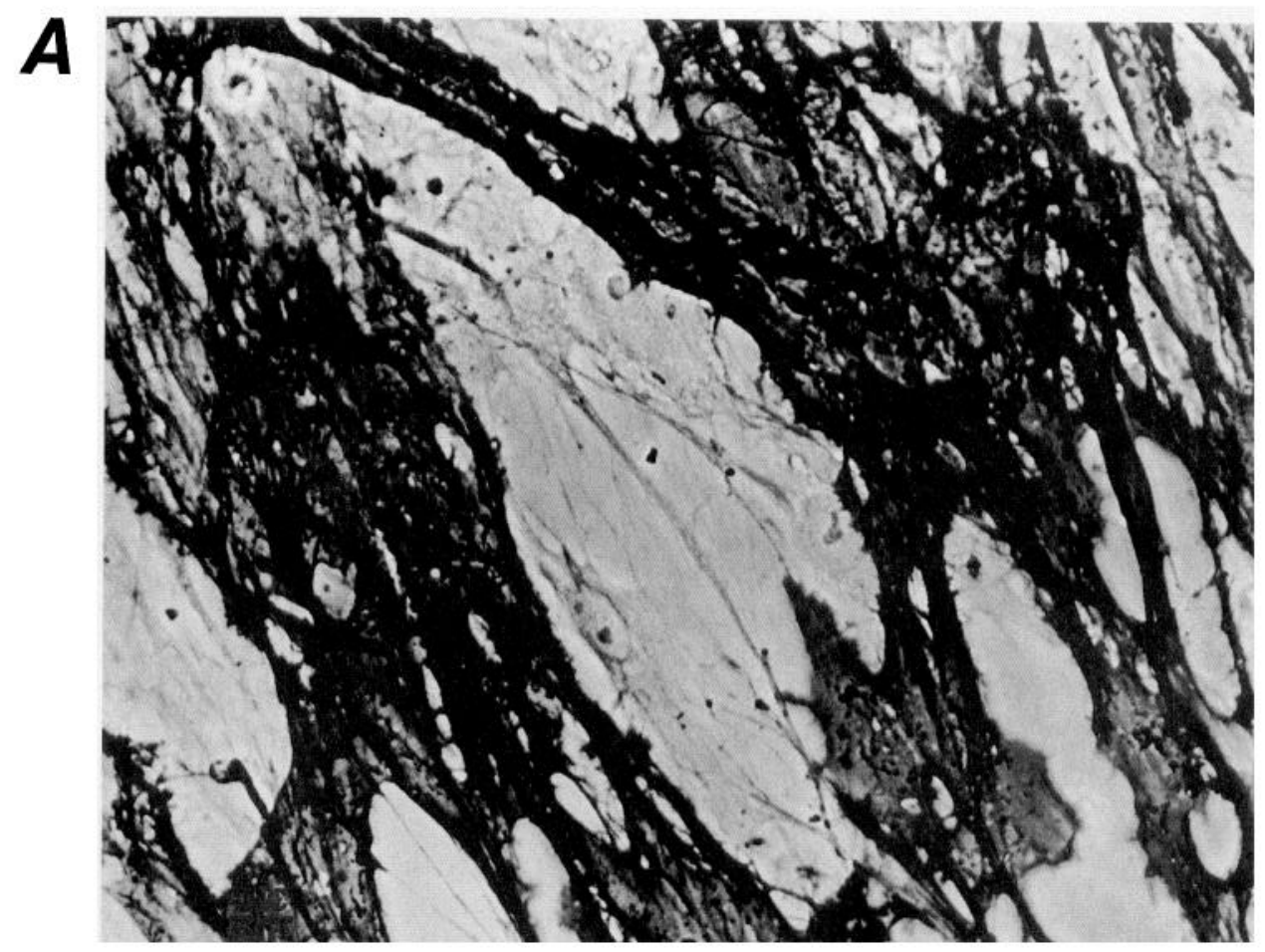

Figure 2. DRG glia are immunopositive for the low-affinity NGF receptor. $A$ shows a phase-contrast micrograph of a field of DRG glia. Immunocytochemistry was performed on cultures using an antibody specific for the lowaffinity NGF-receptor which is expressed in Schwann cells after axotomy. $B$ shows a bright-field image of the same cells. Most of the glia are immunopositive indicating that they are Schwann cells.

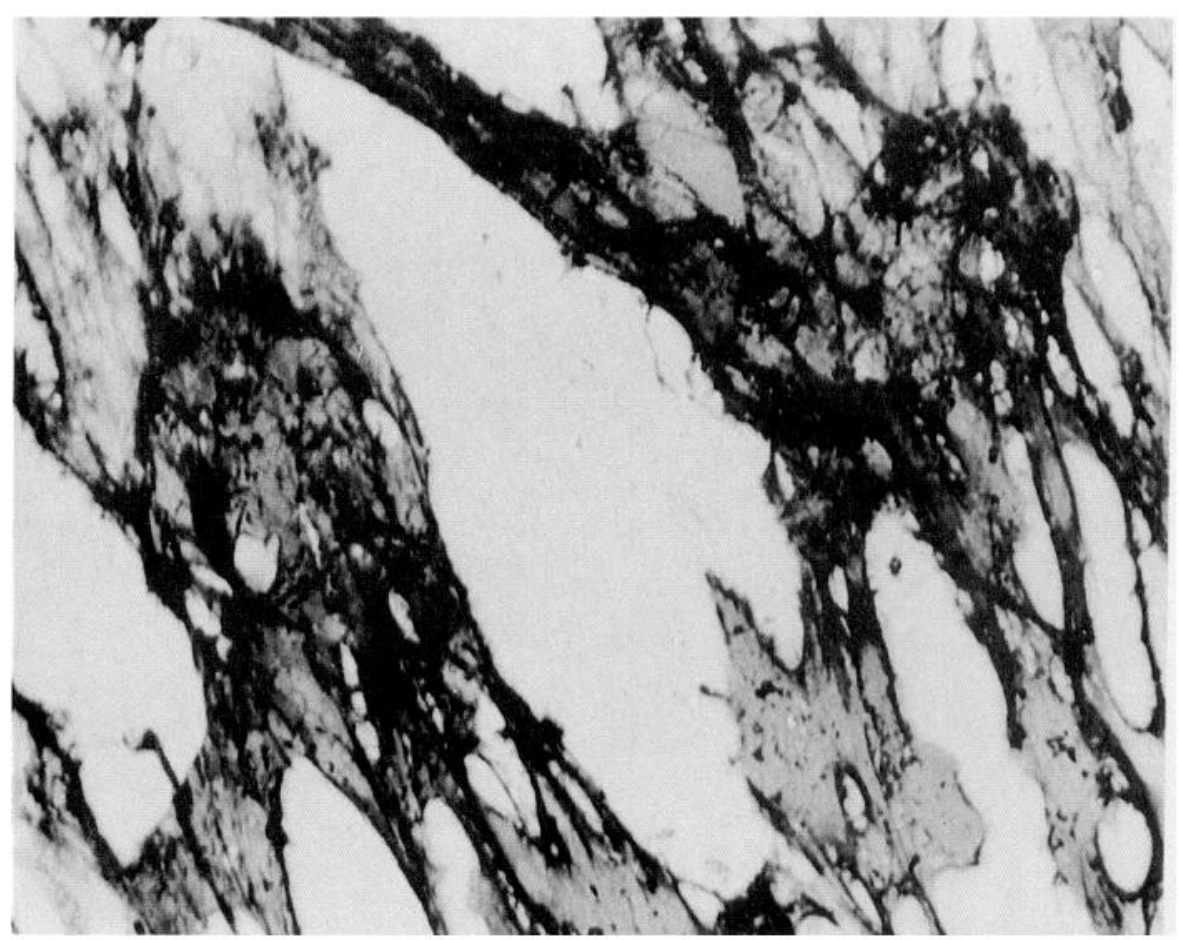

from internal stores and that these stores must refill with calcium from the extracellular medium.

Calcium mobilization from an internal store is further supported by observations using thapsigargin, an inhibitor of the $\mathrm{Ca}^{2+}$-ATPase of internal calcium stores. Following the first addition of bradykinin, thapsigargin $(1 \mu \mathrm{M})$ was added to the cul- ture to prevent reloading of internal stores with calcium. Addition of thapsigargin alone caused a transient increase in calcium from $90 \pm 5$ to $320 \pm 42 \mathrm{nM}(n=15$; Student's $t$ test, $p<$ $0.0001)$. In the presence of thapsigargin, a second application of bradykinin failed to mobilize internal calcium as compared to matched control cells which were incubated in the DMSO carrier 
$\Lambda$

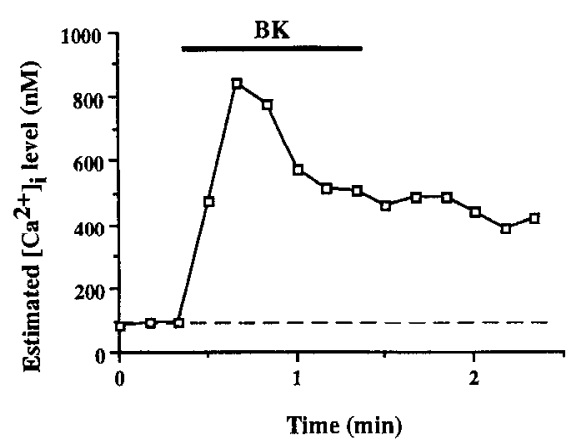

B

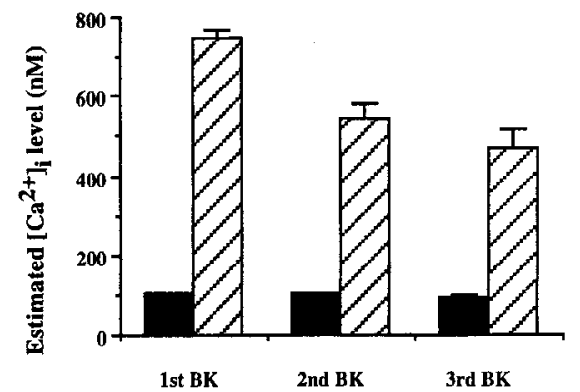

C

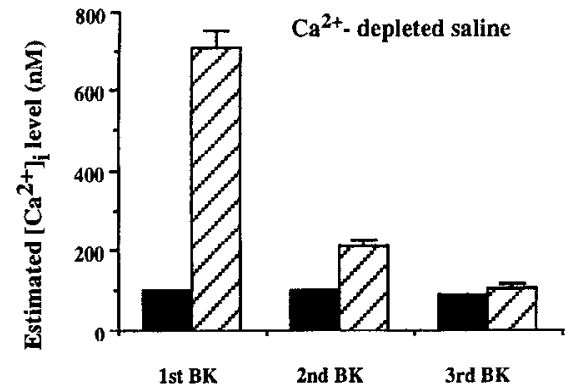

Figure 3. Bradykinin mobilizes $\mathrm{Ca}^{2+}$ from internal stores in DRG glia. In $(A)$ a focal application of bradykinin $(B K, 10 \mathrm{nM})$ elevates DRG glial calcium level to a peak $20 \mathrm{sec}$ after the onset of application. During sustained application of bradykinin, glial calcium is maintained at a stable elevated plateau from basal calcium level (dashed line). In $B$ repeated applications of bradykinin ( $10 \mathrm{nM})$ caused repeated elevations of glial cytoplasmic calcium levels. In $C$ the external calcium was reduced by exchange of normal saline for calcium-depleted saline. In this saline bradykinin was able to elevate calcium from its resting level indicating that calcium is mobilized from internal stores. However, a second and third addition of bradykinin had little effect on internal calcium levels (compare $C$ with $B$ ). Bars represent means \pm SEM.

saline ( $n=26$; Scheffe's test, $p<0.001$; Fig. 4) supporting the notion that bradykinin mobilizes calcium from an internal store. To determine the type of internal calcium store which bradykinin acts on, we added ryanodine, which can block the release of calcium from the caffeine-sensitive calcium store. Ryanodine $(10 \mu \mathrm{M})$ did not affect the calcium mobilizing action of repeated applications of bradykinin $(n=21$ and $n=20$ for the second and third applications, respectively; Scheffé's test, $p>0.25$; Fig. $4 C$ ). Furthermore, the sustained presence of caffeine $(10 \mathrm{~mm})$ did not affect the calcium-mobilizing action of bradykinin $(n=$ 23; Scheffé's test, $p>0.25$; Fig. $4 C$ ). Thus, we conclude that bradykinin predominantly mobilizes calcium from a ryanodine/ caffeine-insensitive internal calcium store. This suggests that bradykinin's actions are mediated through an $\mathrm{IP}_{3}$-sensitive calcium store. This is consistent with other studies which have
A

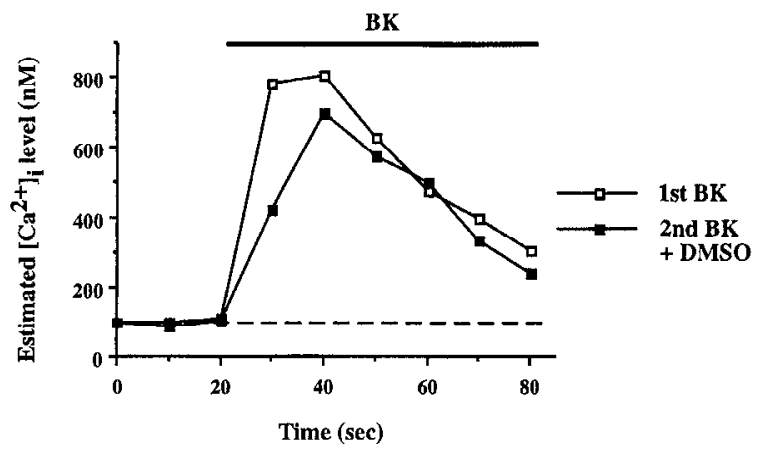

B

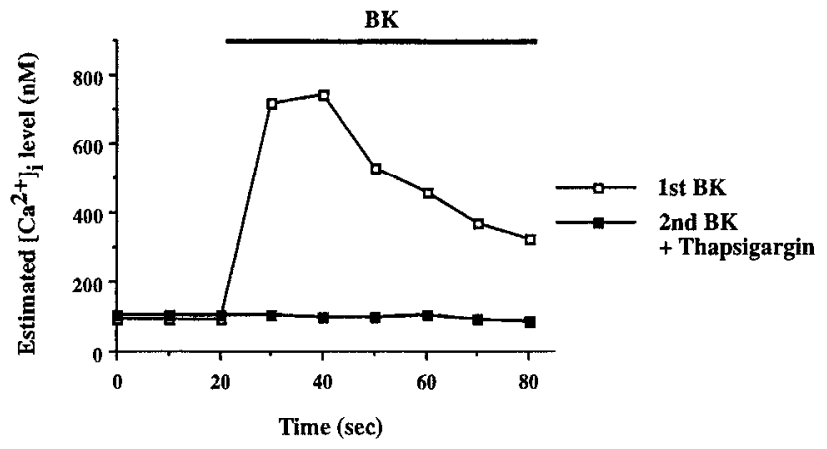

C

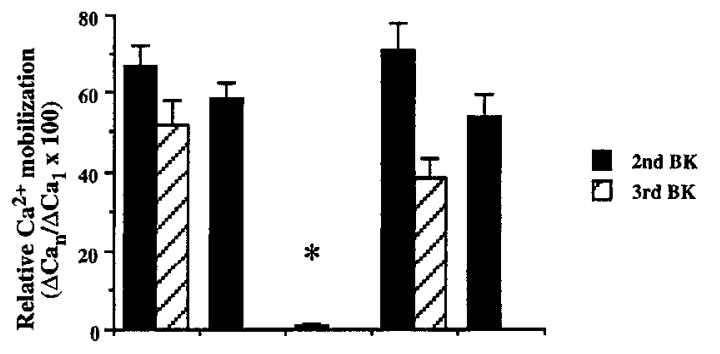

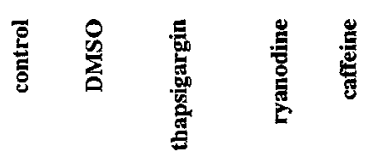

Figure 4. Bradykinin mobilizes calcium from internal calcium stores. $A$, Two applications of bradykinin $(B K, 10 \mathrm{nM})$ reliably elevate internal Schwann cell calcium. Addition of DMSO $(0.1 \% \mathrm{v} / \mathrm{v})$ did not attenuate the bradykinin induced calcium response. $B$, Addition of thapsigargin $(1 \mu \mathrm{M})$ in DMSO following the first addition of bradykinin, prevented subsequent applications of bradykinin from mobilizing internal calcium. $C$, Relative $\mathrm{Ca}^{2+}$ mobilization is expressed as percentage values of $\left[\mathrm{Ca}^{2+}\right]_{i}$ accumulation (peak value subtracted from resting; $\Delta \mathrm{Ca}$ ) during the second and third applications of bradykinin $\left(\Delta \mathrm{Ca}_{n}\right)$ compared to the first $\left(\Delta \mathrm{Ca}_{1}\right)$ (relative calcium mobilization $\left.=\Delta \mathrm{Ca}_{n} / \Delta \mathrm{Ca}_{1} \times 100\right)$. The presence of ryanodine (10 $\mu \mathrm{m}$; Molecular Probes) or caffeine $(10 \mathrm{~mm}$; Sigma) in the bathing solution did not prevent bradykinin from elevating $\left[\mathrm{Ca}^{2+}\right]_{i}$. However, thapsigargin ( $1 \mu \mathrm{M}$; Sigma), but not its DMSO $(0.1 \% \mathrm{v} / \mathrm{v})$ carrier, applied to the bath following the first addition of bradykinin, reduced the bradykinin-induced increase of $\left[\mathrm{Ca}^{2+}\right]_{i}$ during the second addition of bradykinin. Taken together, these data demonstrate that bradykinin mobilizes calcium from internal stores and reloading of these stores requires the presence of external calcium. Points (in $A$ and $B$ ) and bars (in $C$ ) represent means \pm SEM. To compare effects of different drugs on effect of bradykinin one-way ANOVA with post hoc Scheffé's comparison was used. Significance was established at $p<0.001\left(^{*}\right)$. 
shown that bradykinin causes phosphoinositide hydrolysis in oligodendrocytes and astrocytes (Ritchie et al., 1987).

\section{Excitatory amino acid release from Schwann cells is calcium dependent}

Calcium-imaging data raise the possibility that bradykinin stimulates EAA release through mobilizing internal calcium. To test whether calcium is necessary for glutamate release we determined whether multiple applications of bradykinin caused glutamate release in calcium-deplcted salinc. Consistent with the ability of bradykinin to mobilize calcium in calcium-depleted saline the first bradykinin application stimulated the release of glutamate from glial cultures $(n=6$, Fig. $5 A$ ) in calcium-depleted saline. However, a second application of bradykinin in calcium-depleted saline did not cause significant glutamate release ( $n=6$; Student's $t$ test, $p>0.5$; Fig. 5A). To further test the calcium hypothesis for glutamate release, we incubated glial cultures for $30 \mathrm{~min}$ in $50 \mu \mathrm{M}$ BAPTA-AM in calcium-containing saline. This membrane permcant calcium chclator blocked the stimulatory action of bradykinin on glutamate release $(n=6$; Student's $t$ test, $p>0.3$; Fig. $5 B$ )

As a critical test of the calcium hypothesis we exposed cultures to the calcium-ionophore, ionomycin, in calcium-containing saline. Ionomycin transports $\mathrm{Ca}^{2+}$ across a variety of lipid bilayers, without the requirement of specific constituents of biological membranes (Blau and Weismann, 1988). It can thus be expected that it provides a uniform entry of $\mathrm{Ca}^{2+}$ across the entire plasma membrane. Addition of ionomycin $(5 \mu \mathrm{M})$ stimulated the release of both glutamate ( $n=6$; Student's $t$ test, $p<$ 0.025 ; Fig. $5 C$ ) and aspartate (data not shown). Ionomycin was without stimulatory effects when glia were bathed in calciumdepleted saline ( $n=6$; Student's $t$ test, $p>0.9$; Fig. $5 C$ ). Taken together, these data demonstrate that calcium is mobilized in Schwann cells coincident with the timing of EAA release. This calcium mobilization is both necessary and sufficient for stimulating the release of EAAs from Schwann cells.

\section{p-Chloromercuriphenylsulfonic acid does not inhibit EAA release from Schwann cells}

Glutamate can be released from cells during depolarization through the reversal of an clectrogenic glutamate uptake carrier (Szwatkowski et al., 1990). To determine whether this mechanism might regulate glutamate release from DRG Schwann cells, we depolarized them using elevated potassium saline. Application of elevated $\mathrm{K}^{+}(50 \mathrm{~mm})$ did not cause a change in Schwann cells calcium levels ( $n=27$; Student's $t$ test, $p>0.1$ ) nor stimulated EAA release from DRG glia. In control conditions we detected $48 \pm 7 \mathrm{nM}$ glutamate in the superfusate. Following addition of $50 \mathrm{mM} \mathrm{K}^{+}$saline we detected $46 \pm 6 \mathrm{nM}$ glutamate ( $n=6$; Student's $t$ test, $p>0.7$ ). The lack of glutamate release from DRG glia during the application of elevated $\mathrm{K}^{+}$saline is not consistent with a role for the reversal of a glutamate uptake carrier in mediating the bradykinin-induced release of EAAs from DRG Schwann cells. Furthermore, addition of the glutamate transporter inhibitor $p$-chloromercuriphenylsulfonic acid (p-CMPS; $50 \mu \mathrm{M}$ ) did not reduce the bradykinin stimulation of glutamate and aspartate release. However, consistent with previous observations using glutamate transporter inhibitors (Balcar and Johnston, 1971; Isaacson and Nicoll, 1993), p-CMPS did elevate the basal level of glutamate in the bathing medium.
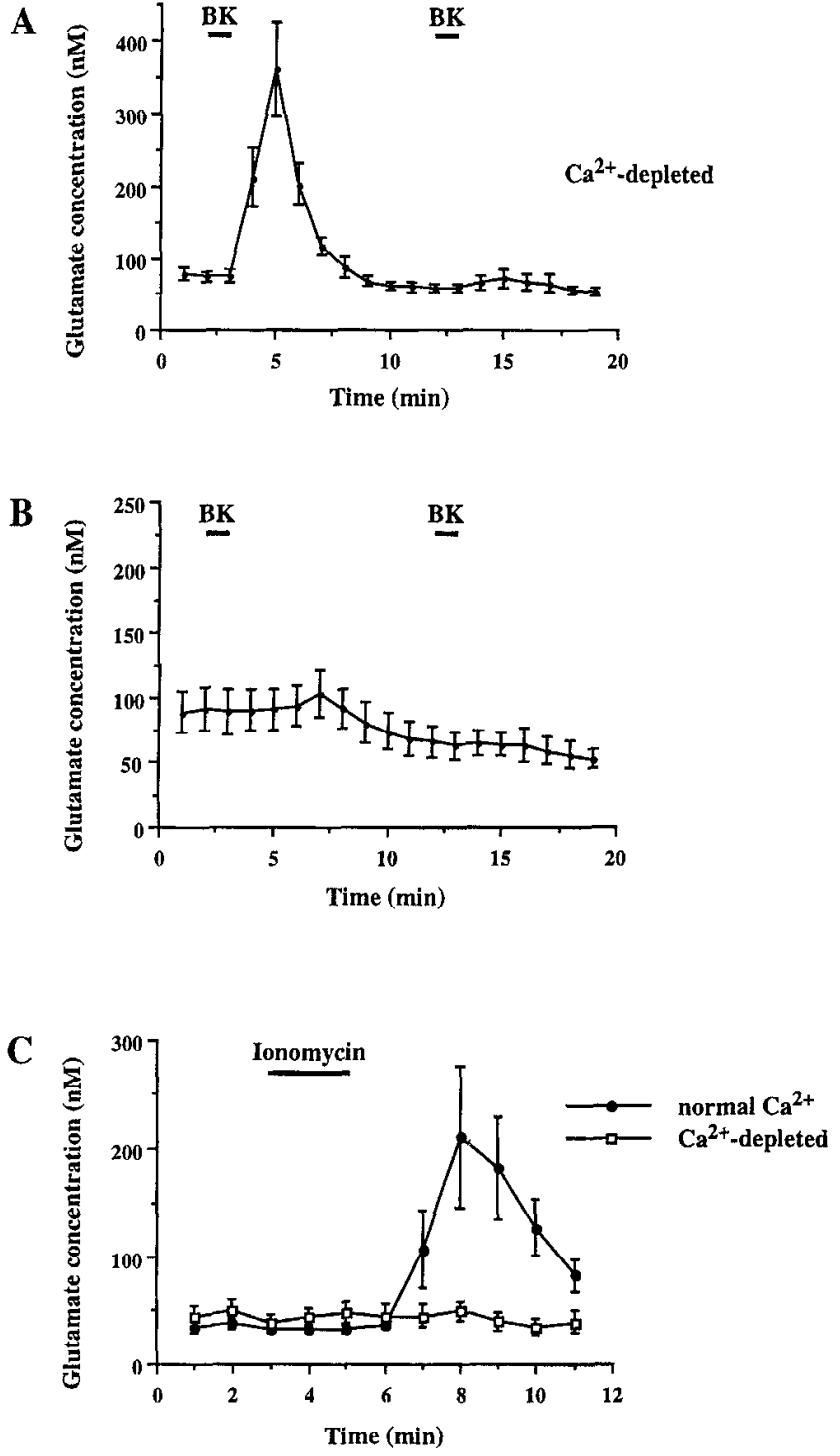

Figure 5. Calcium is necessary and sufficient for glutamate release from DRG glia. The first application of bradykinin $(B K)$ caused glutamate release from glial cells bathed in calcium-depleted saline. However, a second application of bradykinin failed to produce significant release of glutamate $(A)$. After incubation with BAPTA-AM $(50 \mu \mathrm{M}$; Molecular Probes) for $30 \mathrm{~min}$, cells were unable to release glutamate in response to bradykinin showing that increase of intracellular calcium is necessary for glutamate release $(B)$. Sufficiency of calcium to induce glutamate release has been established using ionomycin. Cells released glutamate after application of ionomycin when bathed in normal calcium saline, but not when bathed in calcium-depleted saline $(C)$. In both calcium-depleted and BAPTA treated cells, there was a slight augmentation of basal glutamate levels in the supernatant. Points represent means \pm SEM

\section{EAA release from Schwann cells is not mediated by a cell swelling-dependent mechanism}

Hyposmotic media cause a swelling-dependent release of aspartate and taurine from cortical astrocytes (Kimelberg et al, 1990). This release is sensitive to anion transport inhibitors. We determined whether Schwann cells have a similar sensitivity by incubating them in furosemide $(5 \mathrm{mM})$. Bradykinin-induced release of glutamate was reduced by $98 \%(n=5 ; p<0.001$, Student's $t$ test) in the presence of furosemide (Fig. 61). To ask whether furosemide inhibits glutamate release by acting at the 
A

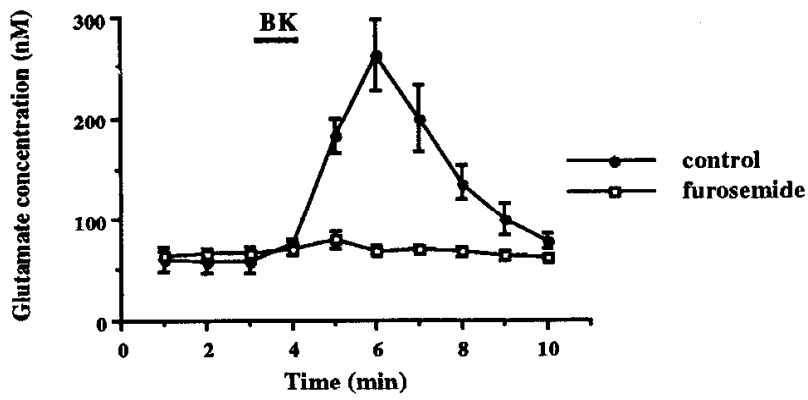

B

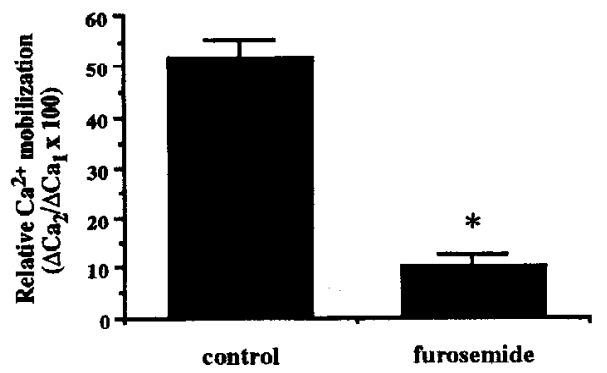

C

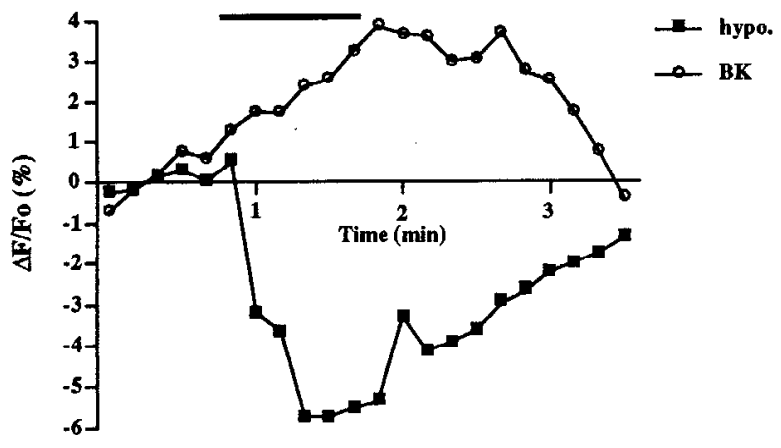

$\mathbf{D}$

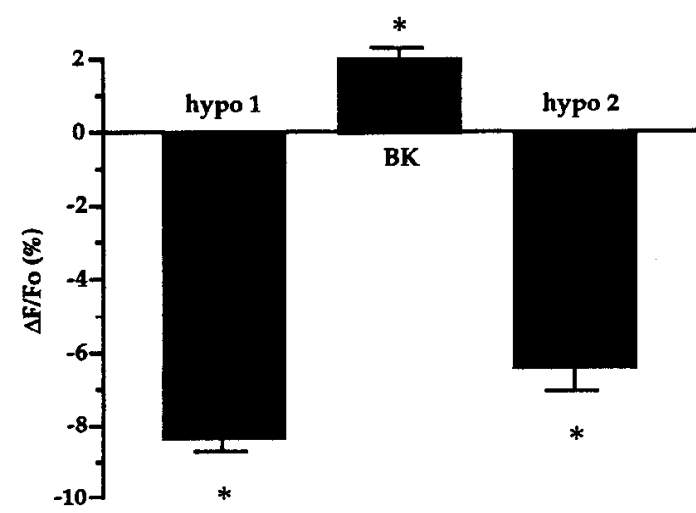

Figure 6. Furosemide, an anion transporter blocker, inhibits bradykinin-induced glutamate release from Schwann cells. In $A$ an application of bradykinin in presence of furosemide ( $5 \mathrm{mM}$, Sigma) did not cause glutamate release from Schwann cells. In parallel, bradykinin-induced calcium mobilization is greatly attenuated by the presence of furosemide in bathing medium $(B)$. Relative $\mathrm{Ca}^{2+}$ mobilization is expressed as percentage values of $\left[\mathrm{Ca}^{2+}\right]_{i}$ accumulation (peak value subtracted from resting; $\Delta \mathrm{Ca})$ during the second application of bradykinin $\left(\Delta \mathrm{Ca}_{2}\right)$ compared to the first $\left(\Delta \mathrm{Ca}_{1}\right)$ (relative calcium mobilization $\left.=\Delta \mathrm{Ca}_{2} / \Delta \mathrm{Ca}_{1} \times 100\right)$. $C$ and $D, B C E C F-l o a d e d ~ S c h w a n n$ cells were used to determine the effect of bradykinin on cell volume. BCECF emission intensity, in response to excitation at $440 \mathrm{~nm}$, was used to monitor cell volume. In $C$ time-lapse of a single BCECF loaded Schwann cell stimulated with hyposmotic saline and bradykinin is shown. Addition of hyposmotic saline significantly reduced the fluorescence intensity which corresponds to cell swelling $(C, D)$. Quite the contrary, subsequent addition of bradykinin at a concentration of $10 \mathrm{nM}$, which stimulates calcium level of the calcium signal we determined the effect of furosemide on bradykinin-induced calcium mobilization. Using repeated applications of bradykinin (see Fig. 4 for protocol) we found that addition of furosemide (5 IIm) significantly attenuated ( $n=43 ; p<0.001$, Student's $t$ test) the ability of the second application of bradykinin to mobilize calcium (Fig. $6 B$ ).

Since furosemide reduces bradykinin-induced calcium mobilization, it is not clear whether the release mechanism per se is sensitive to this anion transport inhibitor as has been demonstrated in astrocytes in response to hyposmotic media (Kimelberg et al., 1990). Therefore, to further test whether bradykinin stimulates glutamate release from Schwann cells through a cell swclling mechanism we monitored cell volume during bradykinin application. Schwann cells were loaded with BCECF and the fluorescence emission was monitored in response to excitation at the $\mathrm{pH}$-insensitive wavelength of $440 \mathrm{~nm}$. Sequential additions of hyposmotic media repeatedly and reversibly reduced the intensity of BCECF fluorescence demonstrating that this method can detect swelling of Schwann cells (Fig. $6 C, D ; n=36 ; p<$ 0.001 , paired $t$ test). Application of bradykinin caused a significant increase in the intensity of BCECF fluorescence which corresponds to decrease of cell volume (Fig. $6 C, D ; 2.0 \pm 0.3 \%$; $n=36 ; p<0.001$, paired $t$ test). As bradykinin does not cause swelling ( $n=36 ; p>0.25$, paired $t$ test), it does not liberate EAAs from Schwann cells through a previously described cell swelling-dependent release mechanism.

\section{Discussion}

Our data demonstrate that the release from Schwann cells of the excitatory amino acids, glutamate and aspartate, is regulated by the neuroligand bradykinin. Bradykinin causes the mobilization of calcium from internal stores in Schwann cells within seconds of addition to cultures. This calcium elevation is sustained for several minutes. In parallel cultures, bradykinin releases glutamate and aspartate within one minute of delivery of bradykinin to the superfusion chamber. Thus, the bradykinin-induced calcium elevation is temporally coincident with the release of EAAs raising the possibility that it is required for $E \wedge \Lambda$ release. To test this hypothesis, we asked whether calcium elevations are both necessary and sufficient for EAA release. When we bypassed the bradykinin receptor and directly elevated internal calcium using calcium ionophore EAA release was stimulated as long as a source of calcium was present. The calcium-elevation stimulated by bradykinin was also shown to be necessary for the release of EAAs. When calcium mobilization was blocked using BAPTA-AM or by removing external calcium during repeated bradykinin applications, bradykinin no longer stimulated the release of EAAs from Schwann cells. Taken together these data demonstrate that bradykinin mobilizes internal calcium in Schwann cells which is both necessary and sufficient to stimulate the release of glutamate and aspartate.

A key issue to address is the nature of the release mechanism that is responsible for EAA liberation from Schwann cells (At-

$\leftarrow$

elevations and EAA release, significantly increased the fluorescence intensity. A second addition of hyposmotic saline demonstrated, however, that these cells were still able to respond with increase in cell volume. Points (in $A$ ) and bars (in $B$ and $D$ ) represent means \pm SEM. Student's $t$ test was used to determine the significance of furosemide effect on bradykinin-induced calcium mobilization, while in $(D)$ a paired $t$ test was used. Significance was found to be $p<0.001\left(^{*}\right)$. 
A

Depolarization

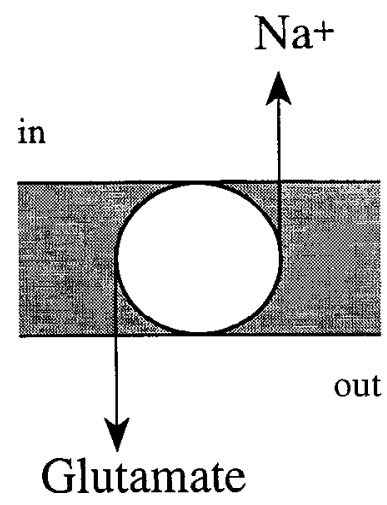

B

Hyposmotic media

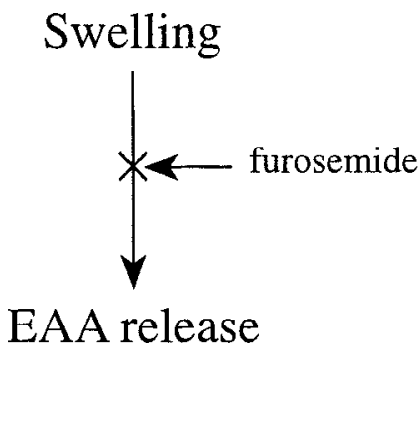

C

Neuroligand

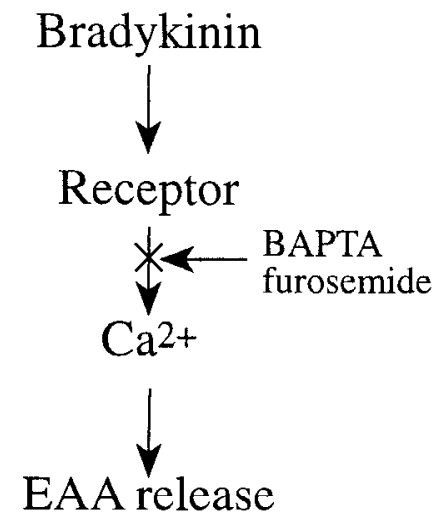

Figure 7. Summary of EAA release mechanisms. Previous studies have demonstrated that EAAs can be released from cells due to $(A)$ the reversal of an electrogenic transporter during depolarization (Szatkowski et al., 1990). Alternatively, hyposinotic medium causes cell swelling which stimulates EAA release that is sensitive to the anion transport inhibitor, furosemide $(B)$ (Kimelberg et al., 1990). Since Schwann cell depolarization does not induce EAA release, the glutamate transport inhibitor p-CMPS does not inhibit bradykinin stimulated EAA release and since bradykinin does not induce swelling of Schwann cells, neither of these release mechanisms is likely to be responsible for neuroligand-induced EAA release. The properties of the bradykinin induced EAA release mechanism of Schwann cells are summarized in $(C)$. Bradykinin acts on a $B_{2}$ receptor which leads to a furosemide-sensitive elevation of calcium. Calcium ions, liberated from internal stores, are both necessary and sufficient to stimulate EAA release from Schwann cells. Further studies are required to determine whether this calcium-dependent release mechanism is similar to the neuronal vesicular release mechanism of synaptic transmission.

twell, 1994; Smith 1994). This release mechanism may take at least three forms (Fig. 7). Glutamate can be released through the reversal of a glutamate transporter (Fig. 7A). Retinal Müller cells, for example, release glutamate in a calcium-independent fashion in response to elevated $\left[\mathrm{K}^{+}\right]_{o}$ due to the reversal of the normal glutamate uptake mechanism (Szwatkovski et al., 1990). This mechanism probably does not account for the release of EAAs in response to bradykinin in DRG Schwann cells since the action of bradykinin is calcium dependent, glutamate release is not stimulated by depolarizing stimuli which would reverse the glutamate uptake carrier and p-CMPS does not block bradykinin-induced release of EAAs.

In cortical astrocytes hyposmotic medium causes cell swelling and the consequent release of glutamate, taurine, and aspartate (Kimelberg et al., 1990; O'Connor and Kimelberg, 1993; Fig. $7 B$ ). An anion transport blocker, furosemide, reduces cell swelling dependent release from cortical astrocytes (Kimelberg et al., 1990). This raises the hypothesis that bradykinin causes cell swelling which in turn stimulates EAA release from Schwann cells. We therefore tested the action of furosemide on EAA release. In Schwann cclls furoscmide reduced bradykinin-stimulated calcium mobilization and EAA release. Since furosemide significantly modified bradykinin-induced calcium signaling this experiment did not allow us to determine whether the cell swelling dependent release mechanism is utilized. Therefore, we directly measured cell volume and asked whether bradykinin induces cell swelling. Using BCECF our data clearly demonstrated that while hyposmotic media induced swelling of Schwann cells, bradykinin did not. These data are not consistent with bradykinin inducing the relcase of EAAs through the previously described volume regulated mechanism (Kimelberg et al., 1990; O'Connor and Kimelherg, 1993). Furthermore, these previous studies have shown that cell swelling induced EAA release is calcium inde- pendent, while calcium is both necessary and sufficient for bradykinin-induced EAA release from Schwann cells.

A third potential Inechanism of bradykinin-stimulated EAA release is through a membrane/vesicle release mechanism similar to that of neurons. Cultures were free of immunoreactivity for the synaptic proteins synaptophysin and synaptotagmin while axons of DRG explants (separate cultures; data not shown) were immunopositive for these synaptic proteins. Thus, proteins characteristic of neuronal transmitter release apparatus are absent in Schwann cells. However, these observations do not rule out quantal membrane release mechanisms since muscle (Dan and Poo, 1992) and fibroblasts (Adler et al., 1993) have been demonstrated competent to release neurotransmitters in a quantal fashion.

Figure $7 C$ summarizes our current understanding of the bradykinin-induced EAA release mechanism. Bradykinin, acting through a receptor, mobilizes internal calcium which is necessary and sufficient to stimulate EAA release from Schwann cells independent of cell volume changes. The nature of this calciumdependent release apparatus remains to be defined.

The regulated relcase of ncurotransmittcrs from glia may be a widespread property. Stimulation of motoneurons leads to the elevation of calcium in the Schwann cells which surround the presynaptic terminal (Jahromi et al., 1992). After denervation, Schwann cells have been shown capable of releasing ACh (Dennis and Miledi, 1974). Depolarization of hippocampal astrocytes causes the calcium-dependent release of the amino acid taurine, but not glutamate (Philibert et al., 1988). Recently, we demonstrated that glial cells from the cerebral cortex release aspartate and glutamate in response to bradykinin (Parpura ct al., 1994). Since many neurotransmitters utilized by the nervous system can mobilize calcium in glia (Reisner et al., 1989; Cornell-Bell et al., 1990; Glaum et al., 1990; Charles et al., 1991; Cornell-Bell 
and Finkbeiner, 1991; Inagaki et al., 1991; Jensen and Chiu, 1991; McCarthy and Salm, 1991), it is possible that neurons have in addition to their fast neuron-neuron synaptic actions, a calcium mobilizing action on neighboring glia (Dani et al., 1992) which in turn leads to the release of other neurotransmitters from glia that may serve secondary roles in glia-neuronal transmission. In support of this possibility recent studies have demonstrated that glia can signal to neurons (Parpura, 1993; Charles, 1994; Nedergaard, 1994; Parpura et al., 1994).

\section{References}

Adler J, Popov S, Girod R, Poo M-m (1993) Calcium-dependent quantal secretion of neurotransmitter from fibroblasts. Soc Neurosci Abstr 19:611.

Attwell D (1994) Glia and neurons in dialogue. Nature 369:707-708.

Balcar VJ, Johnston GAR (1972) The structural specificity of the high affinity uptake of L-glutamate and $\mathrm{L}$-aspartate by rat brain slices. $\mathrm{J}$ Neurochem 19:2657-2666

Barres B (1991) New roles for glia. J Neurosci 11:3685-3694.

Blau L, Weissmann G (1988) Transmembrane calcium movements mediated by ionomycin and phosphatide in liposomes with fura- 2 entrapped. Biochemistry 27:5661-5666.

Charles AC (1994) Glia-neuron intercellular calcium signaling. Dev Neurosci 16:196-206.

Charles AC, Merrill JE, Dirksen ER, Sanderson MJ (1991) Intercellular signaling in glial cells: calcium waves and oscillations in response to mechanical stimulation and glutamate. Neuron 6:983-992.

Cornell-Bell AH, Finkbeiner SM (1991) $\mathrm{Ca}^{2+}$ waves in astrocytes. Cell Calcium 12:185-204.

Cornell-Bell AH, Finkbeiner SM, Cooper MS, Smith SJ (1990) Glutamate induces calcium waves in cultured astrocytes: long-range glial signaling. Science 247:470-473.

Dan Y, Poo M-m (1992) Quantal transmitter secretion from myocytes loaded with acetylcholine. Nature 359:429-440.

Dani JW, Chernjavsky A, Sunith SJ (1992) Neuronal activity triggers calcium waves in hippocampal astrocyte networks. Neuron 8:429 440.

Dennis MJ, Miledi R (1974) Electrically induced release of acetylcholine from denervated Schwann cells. J Physiol (Lond) 237:431-452.

Dray A. Perkins M (1993) Bradykinin and inflammatory pain. Trends Neurosci 16:99-104.

Eriksson PS, Nilsson M, Wågberg M, Rönnbäck L, Hansson E (1992) Volume regulation of single astroglial cells in primary culture. Neurosci Lett 143:195-199.

Gähwiler BH (1984) Slice cultures of cerebellar, hippocampal and hypothalamic tissue. Experientia 40:235-243.

Glaum SR, Holzwarth JA, Miller RJ (1990) Glutamate receptors activate $\mathrm{Ca}^{2+}$ mobilization and $\mathrm{Ca}^{2+}$ influx into astrocytes. Proc Natl Acad Sci USA 87:3454-3458.

Grynkiewicz G, Poenie M, Tsien RY (1985) A new generations of $\mathrm{Ca}^{2+}$ indicators with greatly improved fluorescence properties. J Biol Chem 260:3440-3450.

Higashida H, Ogura A (1991) Inositol triphosphate/calcium-dependent acetylcholine release by bradykinin in NG108-15 rodent hybrid cells. Ann NY Acad Sci 635:153-166.

Hsu S-M, Raine L, Fanger H (1981) Use of avidin-biotin-peroxidase complex $(A B C)$ in immunoperoxidase techniques: a comparison between $\mathrm{ABC}$ and unlabelled antibody (PAP) procedures. J Histochem Cytochem 29:577-580.

Inagaki N, Fukui H, Ito S, Wada $\mathrm{H}$ (1991) Type-2 astrocytes show intracellular $\mathrm{Ca}^{2+}$ elevation in response to various neuroactive substances. Neurosci Lett 128:257-260.

Isaacson JS, Nicoll RA (1993) The uptake inhibitor L-trans-PDC enhances responses to glutamate but fails to alter the kinetics of excit- atory synaptic currents in hippocampus. J Neurophysiol 70:21872191.

Jahromi BS, Robitaille R, Charlton MP (1992) Transmitter release increases intracellular calcium in perisynaptic Schwann cells in situ. Neuron 8:1069-1077.

Jeftinija S, Parpura V, Liu F, Jeftinija K, Haydon PG (1994) Calciumdependent release of excitatory amino acids from Schwann cells. Soc Neurosci Abstr 20:1113.

Jensen AM, Chiu SY (1991) Differential intracellular calcium responses to glutamate in type 1 and type 2 cultured brain astrocytes. J Neurosci 11:1674-1684.

Kanai Y, Smith C P, Hediger MA (1993) The elusive transporters with a high affinity for glutamate. Trends Neurosci 16:365-370.

Kimelberg HK, Goderie SK, Higman S, Pang S, Waniewski RA (1990) Swelling-induced release of glutamate, aspartate and taurine from astrocyte culture. J Neurosci 10:1583-1591.

Kleitman N, Wood PM, Bunge RP (1992) Tissue culture methods for the study of myelination. In: Culturing nerve cells (Banker G, Goslin K, eds), pp 337-377. Cambridge, MA: MIT Press.

Levison SW, McCarthy KD (1992) Astroglia in culture. In: Culturing nerve cells (Banker G, Goslin K, eds), pp 309-336. Cambridge, MA: MIT Press.

Lindroth P, Mopper K (1979) High performance liquid chromatographic determination of subpicomole amounts of amino acids by precolumn fluorescence derivatization with $o$-phthalaldehyde. Anal Chem 51:1667-1674.

Liu F, Jeftinija K, Jeftinija S (1992) Bradykinin selectively releases excitatory amino acids from cultured glia in a calcium-dependent manner. Soc Neurosci Abstr 18:647.

McCarthy KD, Salm AK (1991) Pharmacologically-distinct subsets of astroglia can be identified by their calcium response to neuroligands. Neuroscience 41:325-333.

Miller RJ (1987) Bradykinin highlights the role of phospholipid metabolism in the control of nerve excitability. Trends Neurosci 10:226228.

Nedergaard M (1994) Direct signaling from astrocytes to neurons in cultures of mammalian brain cells. Science 263:1768-1771.

Nicholls D, Attwell D (1990) The release and uptake of excitatory amino acids. Trends Pharmacol Sci 11:462-468.

O'Connor ER, Kimelberg HK (1993) Role of calcium in astrocyte volume regulation and in release of ions and amino acids. J Neurosci 13:2638-2650.

Parpura V (1993) Glia-neuron signaling. Thesis. Iowa State University, Ames.

Parpura V, Basarsky TA, Liu F, Jeftinija K, Jeftinija S, Haydon PG (1994) Glutamate-mediated astrocyte-neuron signaling. Nature 369: 744-747.

Philibert RA, Rogers KL, Allen AJ, Dutton GR (1988) Dose-dependent, $\mathrm{K}^{+}$-stimulated efflux of endogenous taurine form primary astrocyte cultures is $\mathrm{Ca}^{2+}$-dependent. J Neurochem 51:122-126.

Reiser G, Donié F, Binmöller F-J (1989) Serotonin regulates cytosolic $\mathrm{Ca}^{2+}$ activity and membrane potential in a neuronal and in a glial cell line via $5-\mathrm{HT} 3$ and 5-HT2 receptors by different mechanisms. J Cell Sci 93:545-555.

Ritchie T, Cole R, Him H-S, deVellis J, Noble EP (1987) Inositol phospholipid hydrolysis in cultured astrocytes and oligodendrocytes. Life Sci 41:31-39.

Smith SJ (1994) Neuromodulatory astrocytes. Curr Biol 4:807-810.

Szatkowski M, Barbour B, Attwell D (1990) Non-vesicular release of glutamate from glial cells by reversed electrogenic glutamate uptake. Nature 348:443-446.

Taniuchi M, Clark BH, Schweitzer JB, Johnson EM Jr (1988) Expression of nerve growth factor receptors by Schwann cells of axotomized peripheral nerves: ultrastructural location, suppression by axonal contact, and binding properties. J Neurosci 8:664-681.

Thomas AP, Delaville F (1991) The use of fluorescent indicators for measurements of cytosolic-free calcium concentration in cell populations and single cells. In: Cellular calcium (McCormack JG, Cobbold PH, eds), pp 1-54. Oxford: Oxford UP. 